\title{
Superagonistic anti-CD28 antibodies: potent activators of regulatory $T$ cells for the therapy of autoimmune diseases
}

\author{
N Beyersdorf, T Hanke, T Kerkau, T Hünig
}

Ann Rheum Dis 2005;64:iv91-iv95. doi: 10.1136/ard.2005.042564

This paper reviews the existing evidence regarding the use of superagonistic anti-CD28 antibodies (CD28 superagonists) for therapeutic manipulation of regulatory $T$ cells ( $T_{\text {reg }}$ cells). The molecular properties of superagonistic anti-CD28 antibodies allow the generation of a strong activating signal in mature $T$ cells, including $T_{\text {reg }}$ cells, without additional stimulation of the T cell receptor complex. CD28 superagonist administration in vivo leads to the preferential expansion and strong activation of naturally occurring CD4+CD25+CTLA4+FoxP3 $+\mathrm{T}_{\text {reg }}$ cells over conventional $\mathrm{T}$ cells. In animal models, both prophylactic and therapeutic administration of a CD28 superagonist prevented or at least greatly mitigated clinical symptoms and induced remission. Adoptive transfer experiments have further shown that CD28 superagonists mediate protection by expansion and activation of $C D 4+C D 25+T_{\text {reg }}$ cells. Therefore, superagonistic anti-CD28 antibodies offer a promising novel treatment option for human autoimmune diseases and the first clinical trials are eagerly awaited.

\footnotetext{
A
} ccording to the paradigm of costimulation, which was initially adopted from existing concepts of $B$ cell activation, ${ }^{1}$ a T cell needs two signals to become fully activated. Physiologically the "first signal" arises from the interaction of $\mathrm{T}$ cell receptor (TCR) molecules with peptide/ major histocompatibility complex (MHC) complexes on antigen presenting cells (APCs). The "second signal" is provided by the engagement of a so called costimulatory receptor. The first to be discovered and still the most prominent of these costimulatory receptors is CD28. The physiological ligands for CD28, B7.1 and B7.2, are only expressed at high levels by the APC upon prior activation, thereby controlling the initiation of the $\mathrm{T}$ cell response.

To mimic physiological $\mathrm{T}$ cell activation in vitro, monoclonal antibodies (mAbs) with specificity for the TCR complex and CD28 have proved extremely useful. Neither anti-TCR mAbs alone nor "Conventional" anti-CD28 mAbs by themselves suffice to fully stimulate $\mathrm{T}$ cells, whereas a combination of both efficiently induces $\mathrm{T}$ cell proliferation and cytokine secretion (fig 1). Interestingly, however, there is a subclass of CD28 specific antibodies, the CD28 superagonists, which are capable of fully activating $\mathrm{T}$ cells without additional stimulation of the TCR (fig 1). ${ }^{2}$ Moreover, superagonistic anti-CD28 stimulation works not only in vitro but also in vivo as administration of a CD28 superagonist to either rats ${ }^{2}$ or mice (unpublished data) induces a transient but significant increase in overall $\mathrm{T}$ cell numbers. In contrast with-for example, anti-CD3 stimulation-in vivo superagonistic anti-CD28 antibodies do not unleash a toxic "cytokine storm". ${ }^{3}$ Therefore, the lymphocytosis induced by CD28 superagonists appears to be benign and well tolerated.

\section{MOLECULAR PROPERTIES CHARACTERISING SUPERAGONISTIC ANTI-CD28 ANTIBODIES}

As both conventional and superagonistic CD28 specific antibodies, in principle, induce an agonistic signal on interaction with the CD28 molecule, it was important to compare the molecular properties of these two classes of antibody.

Mapping of the binding motifs of anti-CD28 mAbs to the CD28 molecule has revealed that all the conventional antibodies studied bound to a membrane-distal part of CD28, which is close to the B7 binding site (MYPPPY motif) (schematically depicted in fig 2A). ${ }^{4}$ In contrast, superagonistic anti-CD28 antibodies that recognise rat, human, ${ }^{4}$ or mouse CD28 (unpublished data) bind to a lateral, membrane-proximal loop of the molecule ( $\mathrm{C}^{\prime \prime} \mathrm{D}$ loop). Crystallographic analyses of the interaction of a superagonistic anti-CD28 antibody with the extracellular domain of human CD28 further showed that this interaction leads to linear complex formation (schematically presented in fig $2 \mathrm{~B}$ ). ${ }^{5}$ Although conventional anti-CD28 antibodies were also able to bind CD28 bivalently, the resulting complexes were not linear in structure but "tangled". This suggests that in the physiological setting of membrane bound CD28 molecules only CD28 superagonists are capable of mediating formation of complexes by linearly arraying CD28 molecules (fig 2B, C). Complex formation induced by CD28 superagonists, presumably, leads to the aggregation of stimulatory signalling components such as phosphatidylinositol 3-kinase (Pl3K) and growth factor receptor-bound protein 2 (Grb2) and thus to the generation of a strong activating signal.

\section{CD28 SIGNALLING AND IL-2 ARE OF PARTICULAR IMPORTANCE FOR THE GENERATION AND MAINTENANCE OF REGULATORY T CELLS}

Not only the activation of $\mathrm{T}$ cells but also their differentiation in the thymus, and the homoeostasis of the peripheral $\mathrm{T}$ cell pool, are subject to tight control mechanisms. To study the impact of CD28 on T cell homoeostasis, mutant mice, which were deficient for CD28 and/or ligand B7 molecules, were generated. Interestingly, the absence of CD28 signalling in vivo did not affect overall $\mathrm{T}$ cell differentiation and numbers but led to a specific loss of CD4+CD25+ regulatory $\mathrm{T}$ cells $\left(\mathrm{T}_{\text {reg }}\right.$ cells) ${ }^{6}{ }^{7}$ The primary task of $\mathrm{T}_{\text {reg }}$ cells is to keep autoreactive $\mathrm{T}$ cells that have escaped negative selection in the thymus at bay in the periphery (fig 3). ${ }^{8}$ Conversely, a functional and/or numerical deficit in $\mathrm{T}_{\text {reg }}$ cells versus pathogenic autoreactive $\mathrm{T}$ cells leads to the initiation of autoimmunity (fig 3 ). Accordingly, B7 deficient mice, which are devoid of $\mathrm{T}_{\text {reg }}$ cells, showed a higher incidence and an earlier onset of symptoms in a model of human type 1 diabetes. ${ }^{6}$

Abbreviations: AA, adjuvant arthritis; APC, antigen presenting cell; $E A E$, experimental autoimmune encephalomyelitis; TCR, T cell receptor; $\mathrm{T}_{\text {conv }}$ conventional $\mathrm{T}$ cell; $\mathrm{T}_{\text {reg, }}$, regulatory $\mathrm{T}$ cell 


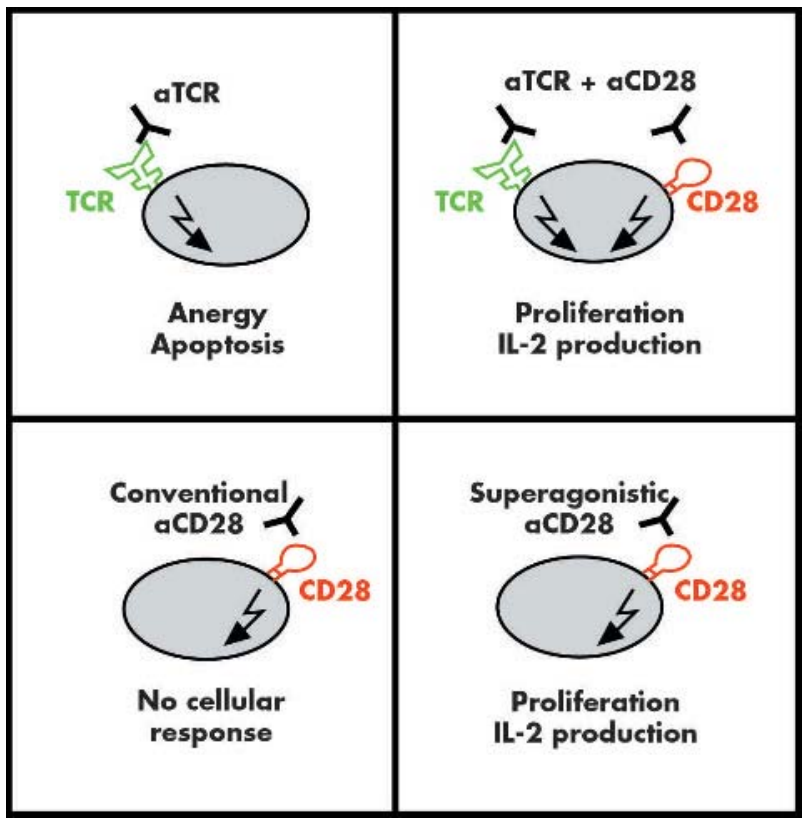

Figure 1 Two classes of CD28 specific monoclonal antibodies (mAbs): "conventional" and "superagonistic". Conventional anti-CD28 mAbs are, only in the context of costimulation, capable of driving interleukin (IL)-2 production and T cell proliferation. In contrast, superagonistic antiCD28 antibodies do not depend on exogenous T cell receptor (TCR)

triggering for full $\mathrm{T}$ cell activation.

Apart from CD28, the cytokine IL-2 has been identified as being crucially involved in the generation and homoeostasis of $\mathrm{T}_{\text {reg }}$ cells. ${ }^{90}$ IL-2 and CD28 were both shown to be essential for thymic development of $\mathrm{T}_{\text {reg }}$ cells and their peripheral maintenance. ${ }^{9-11}$ Further analysis of the role of CD28-B7 interactions in $\mathrm{T}_{\text {reg }}$ cell survival revealed that, on the one hand, $\mathrm{T}_{\text {reg }}$ cells themselves need to receive a signal through CD28, and," ${ }^{11}$ on the other hand, CD28 signalling induces IL-2 production by $\mathrm{CD} 25^{\text {low }}$ conventional $\mathrm{T}$ cells $\left(\mathrm{T}_{\text {conv }}\right)$ which in turn stimulates $\mathrm{T}_{\text {reg }}$ cells. ${ }^{10}{ }^{11}$ In contrast to their "anergic" phenotype upon in vitro stimulation, $\mathrm{T}_{\text {reg }}$ cells, in fact, have a high, CD28 dependent, turnover under steady-state conditions in vivo. ${ }^{7}$ These findings nourished the idea of employing CD28 superagonists in protocols aiming at the therapeutic expansion and activation of $\mathrm{T}_{\mathrm{reg}}$ cells both in vitro and in vivo.

\section{EX VIVO EXPANSION OF $T_{\text {reg }}$ CELLS BY CD28 SUPERAGONISTS AND IL-2}

As $T_{\text {reg }}$ cells seem to be one of the cornerstones of peripheral self-tolerance, novel therapies should aim at re-establishing the balance of autoreactive effector $\mathrm{T}$ cells and $\mathrm{T}_{\text {reg }}$ cells. One way of making use of $\mathrm{T}_{\text {reg }}$ cells therapeutically is to expand them ex vivo and to reinfuse them into animals or patients with autoimmune diseases. As re-transferred $\mathrm{T}_{\text {reg }}$ cells probably survive in the host for long periods of time, one advantage of adoptive cellular immunotherapy with $\mathrm{T}_{\text {reg }}$ cells may be the induction of long term peripheral tolerance. Another advantage is that one can generate $\mathrm{T}_{\text {reg }}$ cells with specificity for the relevant autoantigen allowing antigen specific therapy..$^{12}$

We used CD28 superagonists in conjunction with IL-2 to expand highly purified rat and human CD4+CD25+ T cells in vitro. Expansion of rat $\mathrm{T}_{\text {reg }}$ cells was up to $5 \times 10^{8}$-fold and the cells could be kept in culture for more than 100 days (unpublished data). The expanded $\mathrm{T}_{\text {reg }}$ cells displayed enhanced suppressive activity on a per cell basis compared with freshly isolated regulatory $\mathrm{T}$ cells. Regulatory
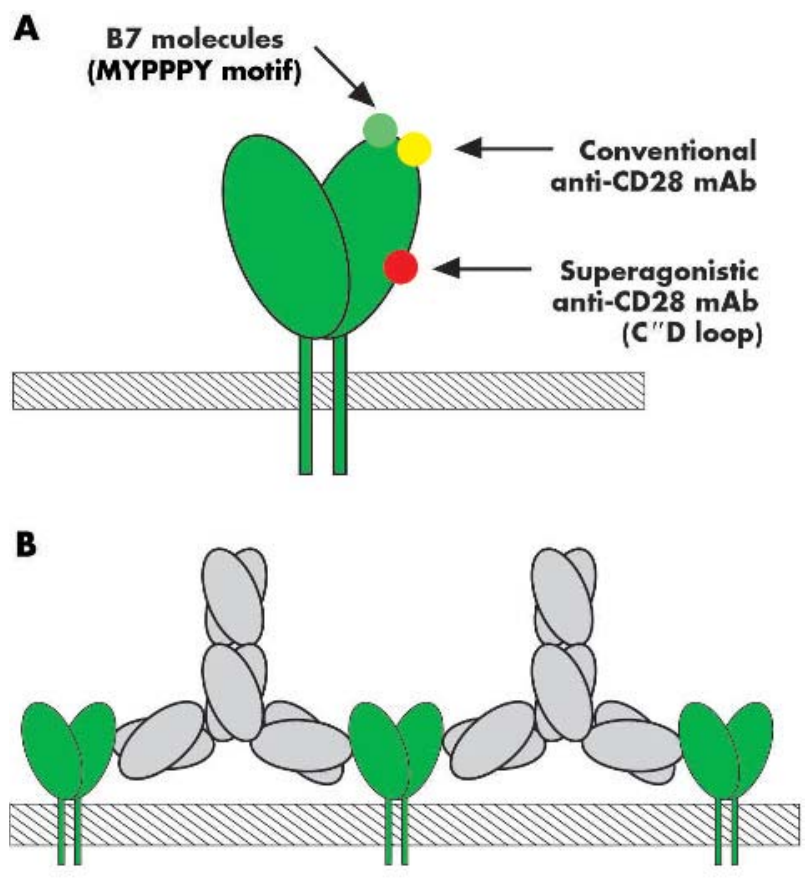

Superagonistic
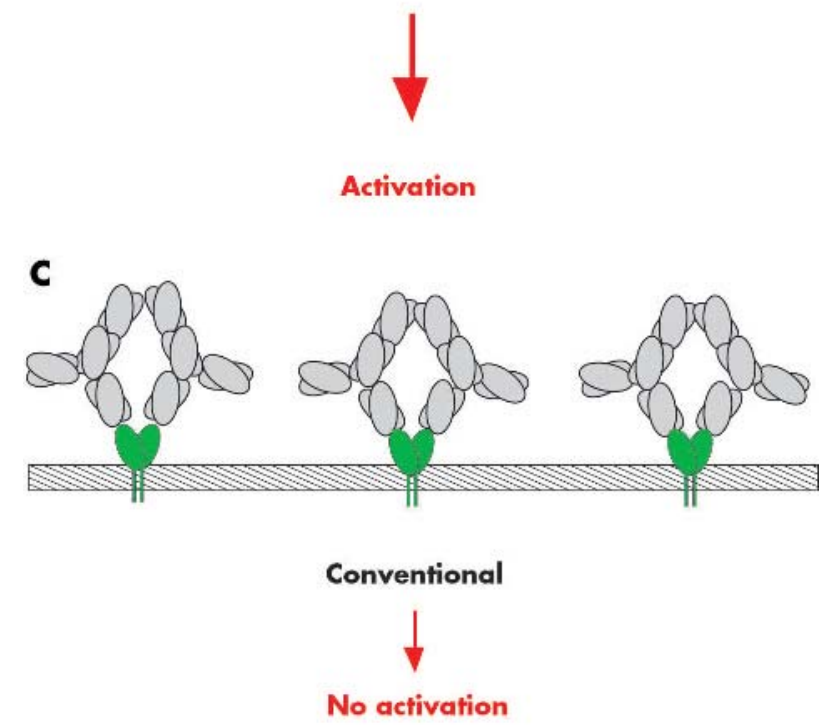

Figure 2 Bivalent linear complex formation could be the molecular clue to superagonistic CD28 stimulation. Only CD28 superagonists (red), but not conventional anti-CD28 antibodies (yellow) or B7 molecules (green), bind to a lateral motif of the CD28 molecule (A). ${ }^{4}$ Therefore, only CD28 superagonists are capable of forming linear complexes with CD28 molecules $(B, C)$. In these complexes activating signalling components, presumably, get aggregated, which is sufficient to surpass the threshold for $T$ cell activation.

$\mathrm{T}$ cell activity, however, remained restricted to the progeny of purified CD4+CD25+ cells, as cultured $\mathrm{T}_{\text {conv }}$ cells did not acquire a suppressive phenotype. Importantly, the expansion of rat $\mathrm{T}_{\text {reg }}$ cells was superior to that of $\mathrm{T}_{\text {conv }}$ cells (unpublished data). This is a big advantage over other, less robust, protocols for in vitro $\mathrm{T}_{\text {reg }}$ cell expansion where the starting population of regulatory $\mathrm{T}$ cells needs to be extremely pure so as not to be overgrown by contaminating $\mathrm{T}_{\text {conv }}$ cells. ${ }^{13}$ 


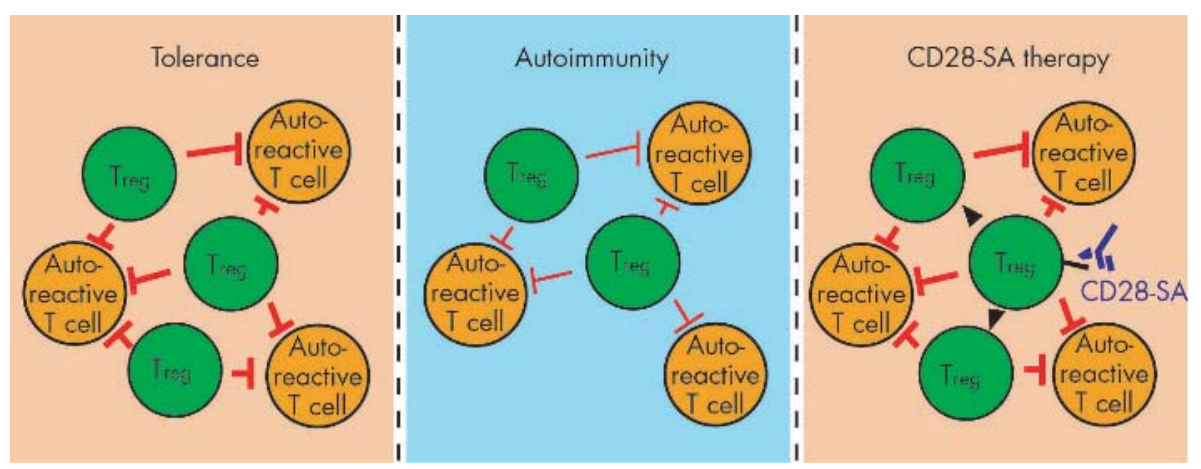

Figure 3 A numerical and/or functional imbalance between autoreactive effector $\mathrm{T}$ cells and regulatory $T$ cells $\left(T_{\text {reg }}\right.$ cells) contributes to the induction and maintenance of autoimmunity. CD28 superagonists are capable of re-establishing peripheral tolerance via the activation and expansion of regulatory $T$ cells.

\section{IN VIVO EXPANSION AND ACTIVATION OF CD4+CD25+ $\mathrm{T}_{\text {reg }}$ CELLS}

Adoptive cellular immunotherapy with ex vivo expanded $\mathrm{T}_{\text {reg }}$ cells recognising the dominant autoantigen is, in principle, an elegant form of therapy in animal models. But, of date, it has not been feasible in most human autoimmune diseases where the relevant autoantigens have not been identified, despite intensive research. Moreover, as the ex vivo expansion of $\mathrm{T}$ cells under good manufacturing practice conditions is expensive and consumes a lot of resources it is unlikely to be broadly applicable in large cohorts of patients.

We thus monitored $\mathrm{CD} 4+\mathrm{CD} 25+\mathrm{T}$ cells after direct application of superagonistic anti-CD28 mAbs to either rats ${ }^{14}$ or mice (unpublished data) in vivo. Application of CD28 superagonists in a dose range from $0.5 \mathrm{mg} / \mathrm{kg}$ to $5 \mathrm{mg} / \mathrm{kg}$ body weight transiently increased the proportion of CD25+ cells among rat CD4+ cells from about 5\% to $20 \%$ (unpublished data). Absolute cell numbers were also significantly increased over the whole dose range-that is, up to 20-fold. But here a clear dose-response effect was observed with higher dosages of CD28 superagonist leading to a stronger increase in $\mathrm{T}_{\text {reg }}$ cell numbers (unpublished data). Importantly, we could segregate expansion of $\mathrm{T}_{\text {reg }}$ cells from induction of gross lymphocytosis by applying low doses of CD28 superagonists (e.g. $0.5 \mathrm{mg} / \mathrm{kg}$ body weight per rat).

Phenotypically, CD28 superagonist administration in vivo leads to the preferential expansion of CD4+CD $25^{\text {bright }}$ CTLA$4^{\text {bright }}$ FoxP3+ cells (unpublished data)—a phenotype defining "natural" $\mathrm{T}_{\text {reg }}$ cells. ${ }^{15-18}$ CD28 superagonists, in fact, induce a true expansion of pre-existing CD4+CD25+ cells because CD4+CD25 - $\mathrm{T}_{\text {conv }}$ cells do not upregulate expression of $\mathrm{CD} 25$ after $\mathrm{CD} 28$ superagonist stimulation in vivo and are, therefore, not recruited into the pool of CD4+CD25+ T cells. ${ }^{14}$

Functional analyses of in vivo CD28 superagonistexpanded CD4+CD25+ T cells revealed a dose dependent increase in suppressive activity per cell compared with CD4+CD25+ $\mathrm{T}_{\text {reg }}$ cells from untreated animals (unpublished data). However, CD4+CD25- cells, even after CD28 superagonist stimulation in vivo, were not able to suppress the proliferation of other $\mathrm{T}$ cells in vitro. In summary, CD28 superagonist administration in vivo leads to the preferential expansion and strong activation of naturally occurring CD4+CD25+CTLA-4+FoxP3+ $\mathrm{T}_{\text {reg }}$ cells over $\mathrm{T}_{\text {conv }}$ cells.

Today, we can only hypothesise as to why $\mathrm{T}_{\text {reg }}$ cells respond more vividly to in vivo $\mathrm{CD} 28$ superagonist stimulation than $\mathrm{T}_{\text {conv }}$ cells. The TCR repertoire of $\mathrm{T}_{\text {reg }}$ cells has been shown to be biased towards recognition of self-antigens. ${ }^{19}$ In fact, it has been postulated that recognition of self-peptides in the thymus actually induces $T_{\text {reg }}$ cell differentiation from thymic precursors. ${ }^{20}{ }^{21}$ Therefore, many, if not all, peripheral $\mathrm{T}_{\text {reg }}$ cells constitutively receive a "first" signal via interaction of their TCR with autoantigens presented by MHC class II molecules leading to hyperphosphorylation of downstream signalling molecules. Such a constitutive first signal may pave the way for the generation of a particularly strong or sustained signal in $\mathrm{T}_{\text {reg }}$ cells upon superagonistic anti-CD28 stimulation. Importantly, this putative triggering of the TCR was, at least in our hands, not sufficient to induce $\mathrm{T}_{\text {reg }}$ cell expansion with the degree of CD28 stimulation reached by conventional antiCD28 antibodies in vivo.

Another possible explanation for the preferential expansion of $\mathrm{T}_{\text {reg }}$ cells over $\mathrm{T}_{\text {conv }}$ cells lies in the antiapoptotic nature of the signals generated by $\mathrm{CD} 28$ superagonist stimulation. ${ }^{22}$ On the one hand, $\mathrm{T}_{\text {reg }}$ cells are, per se, highly prone to undergo apoptosis. Thus, on the other hand, they should particularly benefit from the fact that superagonistic anti-CD28 stimulation not only avoids induction of strong pro-apoptotic signals, mediated by TCR stimulation, but also actively induces antiapoptotic molecules such as BCL- $\mathrm{X}_{\mathrm{L}}{ }^{23}$ Moreover, $\mathrm{T}_{\text {reg }}$ cells are particularly dependent on signals generated by B7-CD28 interactions ${ }^{67}$ and, thus, superagonistic anti-CD28 stimulation probably boosts a pre-existing physiological signal tailored by evolution to promote $\mathrm{T}_{\text {reg }}$ cell proliferation and survival.

Apart from signals directly generated in $\mathrm{T}_{\text {reg }}$ cells, indirect mechanisms such as increased IL-2 synthesis by $\mathrm{T}_{\text {conv }}$ cells and its uptake by $\mathrm{T}_{\text {reg }}$ cells ${ }^{9}{ }^{10}$ could also contribute to the preferential expansion of $\mathrm{T}_{\text {reg }}$ cells over $\mathrm{T}_{\text {conv }}$ cells after superagonistic CD28 stimulation. IL-2 further promotes differentiation of $\mathrm{CD} 4+\mathrm{CD} 25+\mathrm{T}_{\text {reg }}$ cells into producers of the inhibitory cytokine IL-10. ${ }^{24}{ }^{25}$ In addition, CD28 superagonists activate the "cell contact dependent" suppressor machinery which exerts its function only after stimulation of $\mathrm{T}_{\text {reg }}$ cells through the TCR complex- that is, upon recognition of self-antigens in vivo. ${ }^{26}$ Therefore, $\mathrm{T}_{\text {reg }}$ cells probably have an extra edge over $\mathrm{T}_{\text {conv }}$ cells due to active suppression of $\mathrm{T}_{\text {conv }}$ cells during superagonistic CD28 stimulation in vivo.

\section{THERAPEUTIC EFFICACY OF SUPERAGONISTIC ANTI-CD28 ANTIBODIES IN ANIMAL MODELS OF AUTOIMMUNITY}

The preferential expansion of $\mathrm{T}_{\text {reg }}$ cells over $\mathrm{T}_{\text {conv }}$ cells upon superagonistic anti-CD28 stimulation observed in healthy animals gave rise to the concept that $\mathrm{CD} 28$ superagonists might provide a novel form of therapy for autoimmune diseases. Efficacy of CD28 superagonist therapy has so far been evaluated in animal models of both peripheral and central nervous system inflammation as well as in a model of human rheumatoid arthritis.

The neuroinflammatory models employed were experimental autoimmune encephalomyelitis (EAE) of the Lewis rat (monophasic), relapsing EAE of the Dark Agouti (DA) rat and experimental autoimmune neuritis (EAN) of the Lewis rat. EAE is used as an animal model for human multiple sclerosis and EAN resembles many of the clinical and pathological features of Guillain-Barré syndrome, an acute and mostly self-limiting form of peripheral nervous system inflammation in humans. Administration of a CD28 
superagonist in either of these animal models prevented or at least greatly mitigated clinical symptoms when given prophylactically-that is, before the animals showed signs of clinical disease (unpublished data). ${ }^{27}$ Importantly, protection from disease was not restricted to prophylactic administration of the CD28 superagonist. Even after the onset of clinical symptoms therapeutic CD28 superagonist administration rapidly stopped disease progression and induced remission. For successful therapy, as for $\mathrm{T}_{\mathrm{reg}}$ cell expansion, low doses of CD28 superagonist $(0.5 \mathrm{mg} / \mathrm{kg}$ body weight) were sufficient (unpublished data).

To assess the therapeutic efficacy of CD28 superagonists in an animal model of human rheumatoid arthritis, adjuvant arthritis (AA) was induced in Lewis rats by immunisation with heat-killed mycobacteria. Signs of systemic inflammation, such as weight loss, and local arthritic alterations to the joints mark clinical disease. Therapeutic administration of a CD28 superagonist to animals already displaying clinical symptoms halted arthritis progression (unpublished data). Furthermore, rats treated with CD28 superagonists stopped losing and actually resumed gaining weight. Clinical efficacy was paralleled by histological preservation of joint architecture, whereas histological analysis of the ankle joints of untreated animals showed all the stigmata of arthritis (unpublished data). Therefore, CD28 superagonist therapy in this arthritis model was capable of halting clinical disease symptoms and histological manifestations of joint destruction.

\section{PROTECTION FROM AUTOIMMUNITY IS, INDEED, MEDIATED BY CD28 SUPERAGONIST ACTIVATED $T_{\text {reg }}$ CELLS}

The therapeutic efficacy of CD28 superagonists in these models of human autoimmune diseases could, in principle, be independent of the observed expansion and activation of $\mathrm{T}_{\text {reg }}$ cells by CD28 superagonists. For example, activation induced cell death ${ }^{28}$ of pathogenic effector $\mathrm{T}$ cells could be the primary mode of action of superagonistic anti-CD28 therapy. However, we observed that neither was there increased apoptosis of central nervous system infiltrating $\mathrm{T}$ cells after CD28 superagonist therapy of animals with EAE nor did CD28 superagonist stimulation in vitro or in vivo induce apoptosis of effector $\mathrm{T}$ cells in the same animal model (unpublished data). Therefore, activation induced cell death of effector $\mathrm{T}$ cells does not seem to substantially contribute to the efficacy of superagonistic anti-CD28 therapy.

To obtain proof that protection from autoimmunity was mediated by CD28 superagonist-activated CD4+CD25+ $\mathrm{T}_{\text {reg }}$ cells we performed adoptive transfer experiments with purified in vivo CD28 superagonist activated $\mathrm{T}_{\text {reg }}$ cells. Donor animals were primed with a high dose of CD28 superagonist three days prior to isolation of CD4+CD25+ and CD4+CD25 - T cells from the peripheral lymph nodes. On the same day of adoptive transfer of either pure $T_{\text {reg }}$ cells or $T_{\text {conv }}$ cells the recipient animals were also immunised with myelin basic protein in adjuvant for EAE induction. Transfer of CD28 superagonist-activated $\mathrm{T}_{\text {reg }}$ cells clearly protected recipient animals from clinical signs of EAE (unpublished data). Importantly, $\mathrm{CD} 4+\mathrm{CD} 25-\mathrm{T}_{\text {conv }}$ cells purified from the same animals were not protective, even when administered at a 10fold excess compared to the regulatory $\mathrm{T}$ cells.

In summary, CD28 superagonists were proved to be highly efficacious in treating autoimmunity in a number of different animal models, including EAE and adjuvant arthritis of the Lewis rat. Adoptive transfer experiments further showed that CD28 superagonists mediated protection by expansion and activation of CD4+CD25+ $\mathrm{T}_{\text {reg }}$ cells.

\section{APPLICATION OF CD28 SUPERAGONISTS IN HUMAN AUTOIMMUNE DISEASES}

Our preclinical data obtained in animal models of human autoimmune diseases indicated that CD28 superagonists effectively target $\mathrm{CD} 4+\mathrm{CD} 25+$ regulatory $\mathrm{T}$ cells leading to the amelioration of autoimmunity in vivo. Significantly, therapeutic regimens over a broad dose range were never accompanied by detectable side effects. Thus, both the pharmacodynamics and the toxicological profile of $\mathrm{CD} 28$ superagonists support broad applicability of this class of antibody in humans.

Since correlative deficits in $\mathrm{T}_{\mathrm{reg}}$ cell numbers and/or function have also been found in patients with multiple sclerosis $^{29}$ or rheumatoid arthritis, ${ }^{30}$ such patients should clearly benefit from a boost in $\mathrm{T}_{\text {reg }}$ cells with CD28 superagonists. Therefore, superagonistic anti-CD28 antibodies constitute a promising novel treatment option for human autoimmune diseases and the first clinical trials are eagerly awaited.

\section{ACKNOWLEDGEMENTS}

The authors would like to acknowledge the contributions of the following people to the original data referred to in this article: $\mathrm{K} \mathrm{M}$ Dennehy, K Elflein, F Elias, B Geyer, G Hanke, C Lin, F Lühder, M Rodriguez-Palmero, $M$ Tacke, Institute for Virology and Immunobiology, University of Würzburg, Würzburg, Germany; S Gaupp, R Gold, Department of Neurology, University Hospital Würzburg, Würzburg, Germany; S J Davis, E Evans, S Ikemizu, Nuffield Department of Medicine, Oxford University, Oxford, UK; C Guntermann, Y Huang, M Trischler, TeGenero ImmunoTherapeutics AG, Würzburg, Germany; J Wagenaar-Hilbers, M Wauben, Department of Infectious Diseases and Immunology, Division of Immunology, Faculty of Veterinary Medicine, Utrecht University, Utrecht, the Netherlands.

\section{Authors' affiliations}

N Beyersdorf, T Kerkau and T Hünig, Institute for Virology and Immunobiology, University of Würzburg, Würzburg, Germany T Hanke, TeGenero ImmunoTherapeutics AG, Würzburg, Germany

This work was funded by a joint grant from TeGenero ImmunoTherapeutics AG and the Bayerische Forschungsstiffung (forimmun) and by IZKF Würzburg 01 KS 903/Teilprojekt C13 (BMBF).

Competing interests: T Kerkau and T Hünig declare a commercial interest in TeGenero ImmunoTherapeutics AG.

Correspondence to: T Hünig, Institute for Virology and Immunobiology, University of Würzburg, Versbacherstr. 7, 97078 Würzburg, Germany; huenig@vim.uni-wuerzburg.de

\section{REFERENCES}

1 Lafferty KJ, Cunningham AJ. A new analysis of allogeneic interactions. Aust J Exp Biol Med Sci 1975;53:27-42.

2 Tacke M, Hanke G, Hanke T, Hunig T. CD28-mediated induction of proliferation in resting $T$ cells in vitro and in vivo without engagement of the $T$ cell receptor: evidence for functionally distinct forms of CD28. Eur J Immunol 1997;27:239-47.

3 Rodriguez-Palmero M, Hara T, Thumbs A, Hunig T. Triggering of T cell proliferation through CD28 induces GATA-3 and promotes T helper type 2 differentiation in vitro and in vivo. Eur J Immunol 1999;29:3914-24.

4 Luhder F, Huang Y, Dennehy KM, Guntermann C, Muller I, Winkler E, et al. Topological requirements and signaling properties of T cell-activating, antiCD28 antibody superagonists. J Exp Med 2003;197:955-66.

5 Evans EJ, Esnouf RM, Manso-Sancho R, Gilbert RJ, James JR, Yu C, et al. Crystal structure of a soluble CD28-Fab complex. Nat Immunol 2005;6:271-9.

6 Salomon B, Lenschow DJ, Rhee L, Ashourian N, Singh B, Sharpe A, et al. B7/ CD28 costimulation is essential for the homeostasis of the CD4+CD25+ immunoregulatory $\mathrm{T}$ cells that control autoimmune diabetes. Immunity 2000; 12:431-40

7 Tang Q, Henriksen KJ, Boden EK, Tooley AJ, Ye J, Subudhi SK, et al. Cutting edge: CD28 controls peripheral homeostasis of CD4+CD25+ regulatory $T$ cells. J Immunol 2003;171:3348-52.

8 Sakaguchi S. Naturally arising Foxp3-expressing CD25+CD4+ regulatory T cells in immunological tolerance to self and non-self. Nat Immunol 2005;6:345-52. 
9 Malek TR, Bayer AL. Tolerance, not immunity, crucially depends on IL-2. Nat Rev Immunol 2004;4:665-74.

10 Setoguchi R, Hori S, Takahashi T, Sakaguchi S. Homeostatic maintenance of natural Foxp3(+) CD25(+) CD4(+) regulatory T cells by interleukin (IL)-2 and induction of autoimmune disease by IL-2 neutralization. J Exp Med 2005;201:723-35.

11 Tai X, Cowan M, Feigenbaum L, Singer A. CD28 costimulation of developing thymocytes induces Foxp3 expression and regulatory $T$ cell differentiation independently of interleukin 2. Nat Immunol 2005;6:152-62.

12 Tarbell KV, Yamazaki S, Olson K, Toy P, Steinman RM. CD25+ CD4+ T cells, expanded with dendritic cells presenting a single autoantigenic peptide, suppress autoimmune diabetes. J Exp Med 2004;199:1467-77.

13 Tang $Q$, Henriksen KJ, Bi M, Finger EB, Szot G, Ye J, et al. In vitro-expanded antigen-specific regulatory $T$ cells suppress autoimmune diabetes. J Exp Med 2004; 199:1455-65.

14 Lin $\mathrm{CH}$, Hunig T. Efficient expansion of regulatory T cells in vitro and in vivo with a CD28 superagonist. Eur J Immunol 2003;33:626-38.

15 Hori S, Nomura T, Sakaguchi S. Control of regulatory T cell development by the transcription factor Foxp3. Science 2003:299:1057-61.

16 Khattri R, Cox T, Yasayko SA, Ramsdell F. An essential role for Scurfin in CD4+CD25+ T regulatory cells. Nat Immunol 2003;4:337-42.

17 Fontenot JD, Gavin MA, Rudensky AY. Foxp3 programs the development and function of CD4+CD25+ regulatory T cells. Nat Immunol 2003:4:330-6.

18 Fontenot JD, Rasmussen JP, Williams LM, Dooley JL, Farr AG, Rudensky AY. Regulatory $T$ cell lineage specification by the forkhead transcription factor foxp3. Immunity 2005;22:329-41.

19 Hsieh CS, Liang Y, Tyznik AJ, Self SG, Liggitt D, Rudensky AY. Recognition of the peripheral self by naturally arising CD25+CD4+ T cell receptors. Immunity 2004;21:267-77.
20 Jordan MS, Boesteanu A, Reed AJ, Petrone AL, Holenbeck AE, Lerman MA, et al. Thymic selection of $C D 4+C D 25+$ regulatory $T$ cells induced by an agonist self-peptide. Nat Immunol 2001;2:301-6.

21 Apostolou I, Sarukhan A, Klein L, von Boehmer H. Origin of regulatory T cells with known specificity for antigen. Nat Immunol 2002;3:756-63.

22 Kerstan A, Hunig T. Cutting edge: distinct TCR- and CD28-derived signals regulate $\mathrm{CD} 95 \mathrm{~L}, \mathrm{Bcl}-\mathrm{xL}$, and the survival of primary $\mathrm{T}$ cells. J Immunol 2004; 172:1341-5.

23 Acuto O, Michel F. CD28-mediated co-stimulation: a quantitative support for TCR signalling. Nat Rev Immunol 2003;3:939-51.

24 de la Rosa M, Rutz S, Dorninger H, Scheffold A. Interleukin-2 is essential for CD4+CD25+ regulatory T cell function. Eur J Immunol 2004;34:2480-8.

25 Barthlott T, Moncrieffe H, Veldhoen M, Atkins CJ, Christensen J, O'Garra A, et al. CD25+ CD4+ T cells compete with naive CD4+ T cells for IL-2 and exploit it for the induction of IL-10 production. Int Immunol 2005;17:279-88.

26 Thornton AM, Shevach EM. CD4+CD25+ immunoregulatory T cells suppress polyclonal T cell activation in vitro by inhibiting interleukin 2 production. J Exp Med 1998;188:287-96.

27 Schmidt J, Elflein K, Stienekemeier M, Rodriguez-Palmero M, Schneider C, Toyka KV, et al. Treatment and prevention of experimental autoimmune neuritis with superagonistic CD28-specific monoclonal antibodies. J Neuroimmunol 2003;140(1-2): 143-52.

28 Yu XZ, Albert MH, Martin PJ, Anasetti C. CD28 ligation induces transplantation tolerance by IFN-gamma-dependent depletion of $\mathrm{T}$ cells that recognize alloantigens. J Clin Invest 2004;113:1624-30.

29 Viglietta V, Baecher-Allan C, Weiner HL, Hafler DA. Loss of functional suppression by $C D 4+C D 25+$ regulatory $T$ cells in patients with multiple sclerosis. J Exp Med 2004;199:971-9.

30 Ehrenstein MR, Evans JG, Singh A, Moore S, Warnes G, Isenberg DA, et al. Compromised function of regulatory T cells in rheumatoid arthritis and reversal by anti-TNFalpha therapy. J Exp Med 2004;200:277-85. 